\title{
Canada-EU trade agreement expected to increase drug costs
}

$\mathrm{C}$ anada has agreed in principle to a new trade agreement with Europe that grants two more years of patent protection to the manufacturers of brand-name pharmaceuticals, a provision that even the federal government acknowledges will likely drive drug costs up.

Prime Minister Stephen Harper signed the agreement in principle in Brussels, Belgium, on Oct. 18, despite the fact that neither partner has released a final text to its Parliament or made the precise wording public. The federal government claims the deal could increase trade between the two partners by $20 \%$, adding $\$ 12$ billion a year to the Canadian economy and 80000 jobs by providing Canadian businesses with preferential access to the European Union's 500 million consumers.

The federal government is considering a compensation program for the provinces and territories to cover any additional costs of stocking their provincial formularies as a result of the changes, which will effectively extend patent protections to 22 years from the current 20 , limiting the market for cheaper generic drugs. The resulting cost to provinces, territories, employers and consumers could rise by $\$ 1.5$ billion to $\$ 3.5$ billion per year, according to various estimates.

Although the additional patent protection falls short of the five years the European Union was originally demanding, it will still increase health care costs for those without drug plans, says Jim Keon, president of the Canadian Generic Pharmaceutical Association.

"With the two-year extension, the introduction of new generic medicines will be delayed into Canada by an extra two years," says Keon. "Rather than buying a product for 25 cents, you are going to have to continue to buy a product for a dollar."
The additional two years of patent protection will apply only to drugs approved after the deal is passed, International Trade Minister Ed Fast wrote in a letter to Keon.

The trade deal does include some provisions that will help generic drug

Representatives of the brand-name pharmaceutical manufacturers welcome the agreement, saying the increased patent protection compensates for a lengthy regulatory and government approval process and creates a "more level playing field" in intellectual property protection. But Russell Williams, president of $\mathrm{RX} \& \mathrm{D}$, the association that represents brand-name drug makers, insists it is impossible to know for sure if the changes will mean consumers paying more money - either in taxes or out-of-pocket - for drugs.

"Intellectual property does not drive cost," Williams writes in an email. "Europe, for example, benefits from better intellectual property protection than Canada, but has implemented other effective methods to control innovative and generic medicine

manufacturers, including an exception allowing them to continue to produce and market drugs they are exporting to countries with shorter patent protection periods. In addition, the federal government has promised to simplify the patent litigation process, which Keon believes will reduce costs for the generic industry.

"We're hoping that if the system is actually simplified, some of the litigation costs can go into product development and that might actually help our industry," he says.

Overall, the trade deal's intellectual property provisions required Canada to make changes while the European Union does not have to change anything about its patent protection regime. "In pharmaceuticals, this was a net loss for Canada," says Keon. "I think what the government is saying is that it needed to do that in order to get the Europeans to agree to other provisions of the deal." costs, which are also available to our governments."

The changes proposed as part of the trade agreement will be implemented over as many as 10 years, "on medicines that don't even exist today," he writes. "We will continue to work with governments and private drug plans to ensure that Canadians have access to the next generation of new medicines in a sustainable way."

The agreement will stimulate additional investment and more clinical trials in Canada, Williams writes.

"More clinical trials in Canada mean more chances for patients to benefit from potentially life-saving or lifechanging medicines."

Before the agreement takes effect, all 28 EU nations as well as all the provinces and territories must approve it. The process could take up to two years. — Laura Eggertson, CMAJ

CMAJ 2013. DOI:10.1503/cmaj.109-4637 